\title{
Ethanolic extract of Tulipa edulis Bak induces apoptosis in SGC-7901 human gastric carcinoma cells via the mitochondrial signaling pathway
}

\author{
RUHUI LIN ${ }^{1,2}$, ZUANFANG LI ${ }^{1,2}$, JIUMAO LIN $^{1,2}$, JINXIA YE $^{1,2}$, \\ QIAOYAN CAI ${ }^{1,2}$, LIDIAN $\mathrm{CHEN}^{3}$ and JUN PENG ${ }^{1,2}$ \\ ${ }^{1}$ Department of Biomedical Research, Academy of Integrative Medicine; ${ }^{2}$ Fujian Key Laboratory of \\ Integrative Medicine on Geriatrics; ${ }^{3}$ Department of Rehabilitation Medicine, Fujian University of \\ Traditional Chinese Medicine, Fuzhou, Fujian 350122, P.R. China
}

Received May 26, 2014; Accepted March 17, 2015

DOI: 10.3892/ol.2015.3501

\begin{abstract}
Tulipa edulis Bak (TEB) is an active ingredient in various traditional Chinese medicine compounds and is commonly used to treat swelling and redness, remove toxicity and eliminate stagnation, as well as to prevent and treat certain cancer types. However, the underlying molecular mechanism of the anticancer activity of TEB remains unclear. The aim of the current study was to investigate the effect and underlying mechanism of the ethanolic extract of TEB (EETEB) on SGC-7901 human gastric carcinoma cells. An MTT assay was performed to analyze cell viability. In addition, transmission electron microscopy, an Annexin V/fluorescein isothiocyanate assay, a JC-1 assay and laser scanning confocal microscopy with DAPI staining were used to determine the rate of apoptosis. Furthermore, reverse transcription-polymerase chain reaction and western blot analysis were used to detect the expression levels of the apoptosis gene and protein. EETEB was identified to inhibit the growth of SGC-7901 cells in a dose-dependent manner and induce changes in cell morphology. At the molecular level, EETEB induced SGC-7901 cell DNA fragmentation, loss of plasma membrane and asymmetrical collapse of the mitochondrial membrane potential, while it increased the expression of pro-apoptotic B-cell lymphoma-2 (Bcl-2)-associated $\mathrm{X}$ protein and reduced expression of anti-apoptotic Bcl-2. Thus, the results of the current study revealed that the application
\end{abstract}

Correspondence to: Professor Jun Peng, Department of Biomedical Research, Academy of Integrative Medicine, Fujian University of Traditional Chinese Medicine, 1 Huatuo Road, Minhou Shangjie, Fuzhou, Fujian 350122, P.R. China

E-mail:pjunlab@hotmail.com

Professor Lidian Chen, Department of Rehabilitation Medicine, Fujian University of Traditional Chinese Medicine, 1 Huatuo Road, Minhou Shangjie, Fuzhou, Fujian 350122, P.R. China

E-mail: lidianchen87@163.com

Key words: gastric carcinoma cells, mitochondrial signaling pathway, Pseudobulbus Cremastrae seu Pleiones, apoptosis, ultrastructure of EETEB may inhibit the growth of the SGC-7901 cells due to mitochondria-mediated apoptosis.

\section{Introduction}

Gastric cancer (GC) is the most commonly-diagnosed cancer with the second highest mortality rate worldwide (1). In Asian countries, the prognosis for early-stage GC is good; however, the five-year survival rate is only $40 \%$ (2). Furthermore, although surgery, chemotherapy and radiation therapy are predominantly used for the treatment of GC, the median overall survival is $<1$ year (3). Due to the lack of currently available effectual treatment strategies for patients with advanced GC patients, the development of novel therapeutic approaches for the treatment of this life-threatening disease is crucial (4). Plants are considered to be one of the most important sources for the development of novel anticancer agents, with plant-derived agents typically exhibiting relatively fewer side-effects. Various plants have been used in clinical practice in China for thousands of years as important alternative treatments for a variety of diseases. Tulipa edulis Bak (TEB), a Chinese herb, appears to exhibit a curative effect on swelling and redness, removing toxicity and eliminating stagnation (5). In addition, TEB has been used to treat various diseases, such as furunculosis, as well as liver, gastric and breast cancer (6). However, the precise mechanism of the potential antitumor activity of TEB in GC has yet to be investigated.

Anticancer agents commonly target cancer cells through the induction of cell apoptosis, typically by targeting the mitochondrial signaling pathway (7). The B-cell lymphoma-2 (Bcl-2) family of proteins includes critical apoptosis regulators, such as the apoptotic suppressor Bcl-2, and promoters, such as Bcl-2-associated X protein (Bax) (8-12). Bax and Bcl-2 are typically considered as the molecular hallmarks of apoptosis (13). In mammalian cells, intrinsic apoptotic signaling leads to mitochondrial outer membrane (MOM) permeabilization, the release of apoptogenic factors (such as cytochrome $c$ ) and the subsequent activation of caspase protein expression (14). Thus, one possible mechanism through which the proteins of the $\mathrm{Bcl}-2$ family regulate apoptosis is by altering 
the MOM permeability following homo- or hetero-association (15). During the early apoptosis of cancer cells, the MOM is known to change; thus, the anti-apoptotic $\mathrm{Bcl}-2$ protein may bind to active Bax in order to prevent damage to the MOM (16). During the process of apoptosis, cell fate appears to be determined by the ratio of active anti- and pro-apoptotic Bcl-2 family members (17). This ratio is altered by aberrant expression of Bax and Bcl-2 proteins, impairing the normal apoptotic program and contributing to various apoptosis-associated diseases. Therefore, controlling the permeability of mitochondria using $\mathrm{Bcl}-2$ family proteins ultimately results in mitochondrial changes that induce cell apoptosis (18). Previously, it has been demonstrated that treatment with ethanolic extract of TEB (EETEB) resulted in a decreased number of microvilli and shrinkage of the cytoplasmic organoid volume in human gastric carcinoma SGC-7901 cells, indicating that TEB may induce apoptosis at the molecular level (19).

Thus, the aims of the present study were to investigate the effect of EETEB on the apoptosis of SGC-7901 human GC cells and determine the possible molecular mechanisms underlying this effect.

\section{Materials and methods}

TEB alcohol extraction. A preparation of dry TEB extract powder (Tongrentang, Fuzhou, China) was weighed (58.7 g) and added to a 1,000-ml flask with $500 \mathrm{ml} 95 \%$ (v/v) ethanol. The mixture was refluxed at $95^{\circ} \mathrm{C}$ for $3 \mathrm{~h}$. A second sample was mixed with an additional $500 \mathrm{ml} \mathrm{95 \%} \mathrm{(v/v)} \mathrm{ethanol} \mathrm{and}$ a second reflux was performed. The two samples were mixed and concentrated on a rotary evaporator at a temperature of $50^{\circ} \mathrm{C}$ for 48 h. Subsequently, the sample was successively washed two times with distilled water and three times with petroleum ether to obtain the final extract (EETEB), weighing $1.71 \mathrm{~g}$.

Cell culture and cytotoxicity analysis. SGC-7901 human GC cells, from the Tumor Hospital of Fujian (Fujian, China) were grown and maintained in RPMI 1640 medium (Thermo Fisher Scientific, Inc., Waltham, MA, USA) containing 10\% fetal bovine serum, $80 \mathrm{U} / \mathrm{ml}$ penicillin and $80 \mathrm{U} / \mathrm{ml}$ streptomycin (all from Thermo Fisher Scientific, Inc.) at $37^{\circ} \mathrm{C}$ in a humidified atmosphere of $5 \% \mathrm{CO}_{2}$. The SGC-7901 cells were inoculated into 96-well plates at a concentration of $100 \mu \mathrm{l} /$ well and cultured for $24 \mathrm{~h}$. Subsequently, the cells were treated with various concentrations of EETEB $(0.75,1.0$ and $1.5 \mathrm{mg}$ crude $\mathrm{EETEB} / \mathrm{ml})$; the control cells were treated with PBS. Following incubation for $24 \mathrm{~h}, 50 \mu \mathrm{l}$ MTT solution $(1.1 \mathrm{mg} / \mathrm{ml})$ was added to each well and incubated for an additional $4 \mathrm{~h}$. Finally, the medium was replaced with $1.5 \mathrm{mg} / \mathrm{ml}$ MTT and incubated at $37^{\circ} \mathrm{C}$ for $\sim 4 \mathrm{~h}$. The crystallization was resolved using dimethyl sulfoxide and the absorbance was measured using a microplate spectrophotometer (SpectraMax 190; Molecular Devices, LLC, Sunnyvale, CA, USA) at a wavelength of $580 \mathrm{~nm}$.

Apoptosis detection. SGC-7901 cells were seeded into 6-well plates in $2 \mathrm{ml}$ medium and treated with various concentrations of EETEB $(0.75,1.0$ and $1.5 \mathrm{mg} / \mathrm{ml})$ for $24 \mathrm{~h}$. Flow cytometric analysis with an Annexin V-fluorescein isothiocyanate (FITC)/propidium iodide (PI) kit (BD Biosciences,
Franklin Lakes, NJ, USA) was used to detect the apoptosis of SGC-7901 cells. The staining procedure was performed according to the manufacturer's instructions. In the apoptosis assay, an Annexin V/PI double-negative population [labeled as LL in the fluorescence-activated cell sorting (FACS) diagram] indicated the viable cells; by contrast, an Annexin V-positive/PI-negative or Annexin V/PI double-positive population represented cells undergoing early or late apoptosis, respectively.

Apoptosis analysis using DAPI staining. DAPI staining followed by laser scanning confocal microscopy (LSCM; LSM 710; Carl Zeiss AG, Oberkochen, Germany) was used to detect the apoptosis of the SGC-7901 cell nuclei. A minimum of $5 \times 10^{4}$ cells treated with various concentrations of EETEB $(0.75$, 1.0 and $1.5 \mathrm{mg} / \mathrm{ml}$ ) were evaluated per chamber. A 488-nm, 10-MW argon laser beam was used for excitation of blue DAPI fluorescence. Subsequently, LSCM was performed to observe the nuclei of the SGC-7901 cells and detect apoptosis. The collected data were analyzed using Microsoft Excel 2000 software (Microsoft Research, Redmond, WA, USA).

Cell ultrastructure. The cell lysates were collected by centrifugation at $15,000 \mathrm{x} \mathrm{g}$ for $10 \mathrm{~min}$ at $25^{\circ} \mathrm{C}$, the cells treated with various concentrations of EETEB $(0.75,1.0$ and $1.5 \mathrm{mg} / \mathrm{ml})$ were fixed in $1.5 \%$ paraformaldehyde and $4 \%$ glutaraldehyde in 0.1 M phosphate-buffered saline (PBS) buffer ( $\mathrm{pH}$ 7.2-7.4) for $12 \mathrm{~h}$ at $4^{\circ} \mathrm{C}$. Next, the cells were washed with PBS buffer and post-fixed with $1 \% \mathrm{OsO}_{4}$ in $0.1 \mathrm{M}$ PBS buffer for $2 \mathrm{~h}$. The cells were then dehydrated in a graded ethanol alcohol series and embedded in Epoxy resin 618 (E-51, Ganxi Chemical Co. Ltd., Jiangxi, China). Ultrathin sections (100 nm) were cut using an ultramicrotome (EM UC6; Leica Microsystems $\mathrm{GmbH}$, Wetzlar, Germany). The sections were stained in $2.0 \%$ uranyl acetate for $20 \mathrm{~min}$ and lead citrate for $15 \mathrm{~min}$. Finally, transmission electron microscopy (TEM; H-7650; Hitachi, Ltd., Tokyo, Japan) was used to examine and capture images of the cell sections.

Measurement of mitochondrial membrane potential. The mitochondrial membrane potential was detected using a JC-1 fluorescent probe (Nanjing KeyGen Biotech Co., Ltd., Nanjing, China), which is a cationic dye that exhibits potential-dependent accumulation in mitochondria. A change in JC-1 fluorescence emission from red to green indicates depolarization of the mitochondrial membrane; thus, this dye can be used as an indicator of changes in mitochondrial membrane potential. In the current experiment, following trypsin digestion (Thermo Fisher Scientific Inc.), SGC-7901 cells $\left(1 \times 10^{6}\right)$ treated with various concentrations of EETEB $(0.75,1.0$ and $1.5 \mathrm{mg} / \mathrm{ml}$ ) were resuspended in $1 \mathrm{ml}$ medium and incubated with $10 \mu \mathrm{g} / \mathrm{ml} \mathrm{JC}-1$ at $37^{\circ} \mathrm{C}$ in an atmosphere of $5 \% \mathrm{CO}_{2}$ for 30 min. JC-1 fluorescence was recorded using a FACSCalibur flow cytometer (Becton-Dickinson, Franklin Lakes, NJ, USA) at emission wavelengths of 525 and $590 \mathrm{~nm}$ for green and red fluorescence, respectively.

Reverse transcription-polymerase chain reaction (RT-PCR). SGC-7901 cells ( $1 \times 10^{6}$ cells/well) were seeded into 6-well plates with $2 \mathrm{ml}$ medium and treated with various concentrations of 
EETEB $(0.75,1.0$ and $1.5 \mathrm{mg} / \mathrm{ml})$ for $24 \mathrm{~h}$. Total RNA was extracted from the SGC-7901 cells using a Beyzol reagent kit (Shanghai Biyuntian Bio-Technology Co., Ltd., Shanghai, China). Subsequently, oligo(dT)-primed RNA (1 $\mu \mathrm{g})$ was reverse-transcribed using SuperScript II ${ }^{\circledR}$ Reverse Transcriptase (Promega Corporation, Madison, WI, USA), according to the manufacturer's instructions. PCR was performed to determine the quantity of Bcl-2 and Bax mRNA in the obtained cDNA samples. GAPDH was used as the internal control and the DNA bands were examined using a Gel Documentation system (Gel Doc 2000; Bio-Rad Laboratories, Hercules, CA, USA).

Western blotting. SGC-7901 cells $\left(1 \times 10^{6}\right)$ were seeded in 6 -well plates in $2 \mathrm{ml}$ medium and treated with various concentrations of EETEB $(0.75,1.0$ and $1.5 \mathrm{mg} / \mathrm{ml})$ for $24 \mathrm{~h}$. The cells were washed twice with cold PBS and then lysed in radioimmunoprecipitation assay buffer containing $1 \mathrm{mM}$ phenylmethyl sulfonyl fluoride (Roche Diagnostics GmbH, Mannheim, Germany). Next, the lysates were centrifuged at $12,000 \times \mathrm{g}$ for $10 \mathrm{~min}$ at $4^{\circ} \mathrm{C}$ to acquire the total Bax and Bcl-2 proteins from the mitochondria. The cytosolic and mitochondrial fraction proteins were collected. A single aliquot of the supernatant (50 mg protein) was subjected to electrophoretic separation using SDS-PAGE and transferred to a polyvinylidene fluoride (PVDF) membrane (EMD Millipore, Billerica, MA, USA). The membranes were incubated in blocking buffer (non-fat milk) and then incubated overnight at $4^{\circ} \mathrm{C}$ with rabbit polyclonal antibodies against Bax (1:1,000, 20 kDa, Cell Signaling Technology, Inc., Danvers, MA, USA), Bcl-2 (1:1,000, 26 kDa, Cell Signaling Technology, Inc.) or $\beta$ -actin (1:4,000, $43 \mathrm{kDa}$, Beyotime Institute of Biotechnology, Haimen, China). The membranes were stringently washed and incubated with HRP-conjugated secondary antibodies (Proteintech Group, Chicago, IL, USA), for $1 \mathrm{~h}$ at room temperature. Images were captured using a Kodak Image Station 400R (Eastman Kodak Co., Rochester, NY, USA).

Statistical analysis. All the data are presented as the mean of three experiments and were analyzed using SPSS software (version 16.0; SPSS, Inc., Chicago, IL, USA). Statistically significant differences between the control and treatment groups were obtained by performing one-way analysis of variance. $\mathrm{P}<0.05$ was considered to indicate a statistically significant difference.

\section{Results}

EETEB inhibits the proliferation of SGC-7901 cells. The effect of EETEB on the proliferation of SGC-7901 cells was determined by performing an MTT assay. As demonstrated in Fig. 1, treatment with $0.75,1.0$ and $1.5 \mathrm{mg} / \mathrm{ml}$ EETEB resulted in cell viability of $71.99 \pm 7.26,54.28 \pm 5.28$ and $34.48 \pm 5.84 \%$, respectively. These values were significantly higher compared with the untreated control cells $(\mathrm{P}<0.05)$, indicating that EETEB inhibited SGC-7901 cell proliferation in a dose-dependent manner.

EETEB induces the apoptosis of SGC-7901 cells. To determine whether the cell-growth suppressive effect of EETEB

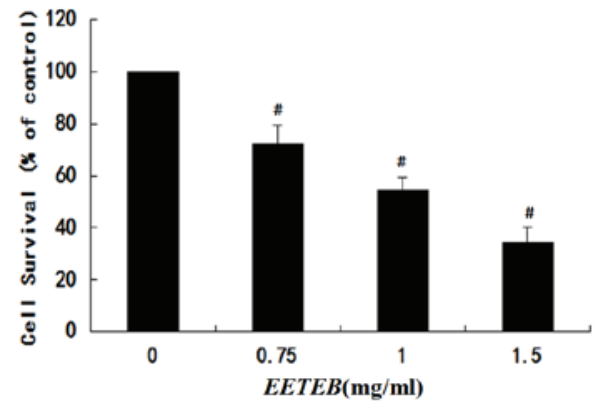

Figure 1. Effect of EETEB on the viability of SGC-7901 gastric cancer cells. Cells were grown and treated with increasing concentrations of EETEB (up to $1.5 \mathrm{mg} / \mathrm{ml}$ ) for $24 \mathrm{~h}$. Cell viability was analyzed using an MTT assay and data are presented as the mean \pm standard error of the mean of three independent experiments $(\mathrm{n}=3) .{ }^{\#} \mathrm{P}<0.05$ vs. control cells. EETEB, ethanolic extract of Tulipa edulis Bak.
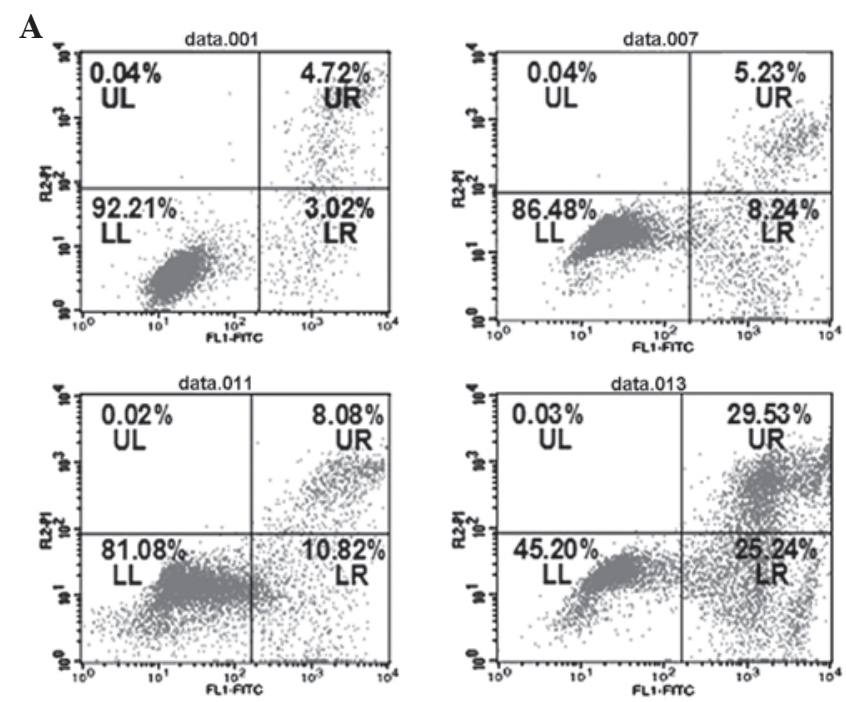

$\mathbf{B}$

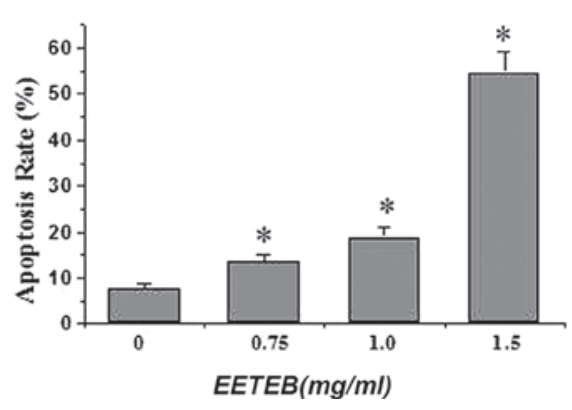

Figure 2. Effect of EETEB on SGC-7901 cell apoptosis. Cells were grown and treated with increasing concentrations of EETEB for $24 \mathrm{~h}$, collected and stained with Annexin V/PI. (A) Representative fluorescence-activated cell sorting (FACS) analysis scattergrams displaying four different cell populations, labeled as: LL, double-negative stained cells = live cell population; LR, Annexin V-positive/PI-negative stained cells - early apoptosis; UR, Annexin V/PI double-positive stained cells - late apoptosis; and UL, Annexin V-negative/PI-positive stained cells - dead cells. Data are representative of three independent experiments. (B) Quantification of FACS analysis. Data are presented as the mean \pm standard error of the mean of three independent experiments $(n=3) .{ }^{*} \mathrm{P}<0.05$, vs. control cells. UP, upper left; UR, upper right; LL, lower left; LR, lower right; PI, propodium iodide; FITC, fluorescein isothiocyanate; EETEB, ethanolic extract of Tulipa edulis Bak.

was due to apoptosis, the pro-apoptotic activity of EETEB on SGC-7901 cells was determined using Annexin-V/PI staining 

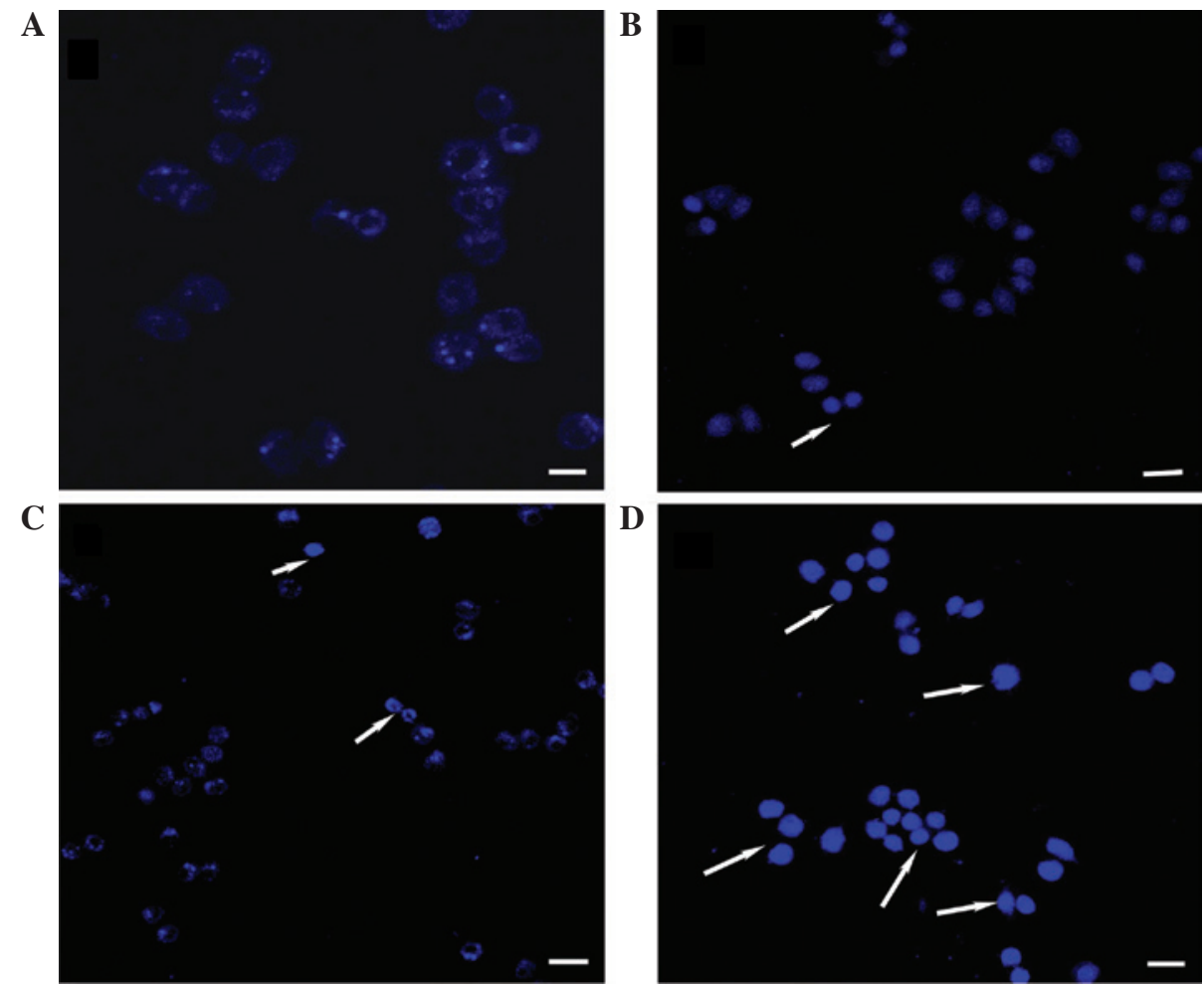

Figure 3. Effect of EETEB on the apoptosis of SGC-7901 cells using DAPI staining. Cells were grown and treated with increasing concentrations of EETEB (up to $1.5 \mathrm{mg} / \mathrm{ml}$ ) for $24 \mathrm{~h}$, followed by laser scanning confocal microscopy. The cells treated with (A) 0 (control group), (B) 0.75 , (C) 1.0 and (D) $1.5 \mathrm{mg} / \mathrm{ml} \mathrm{EETEB}$. Arrows indicate apoptotic cells. Scale bars, $20 \mu \mathrm{M}$. EETEB, ethanolic extract of Tulipa edulis Bak.
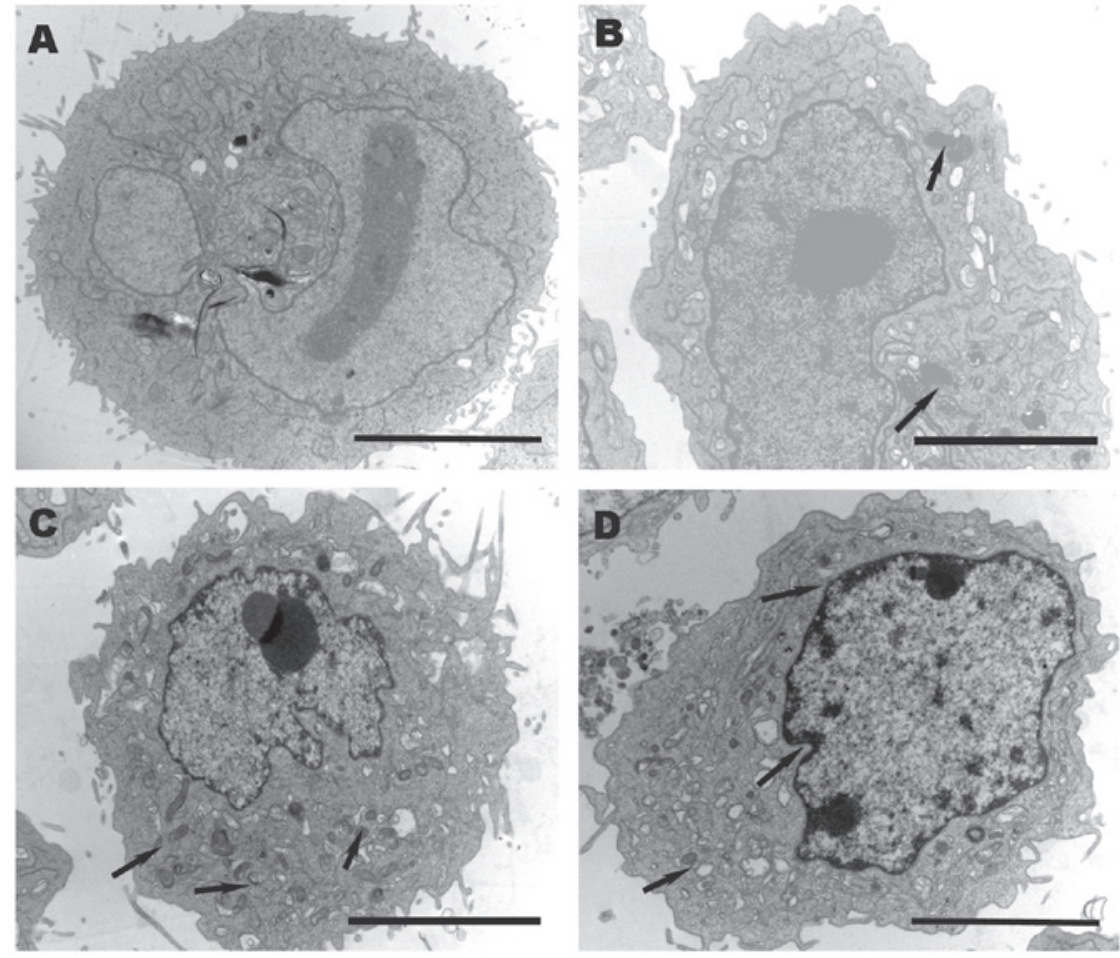

Figure 4. Effect of EETEB on the morphology of SGC-7901 cells, observed using a transmission electron microscope. Cells were grown and treated with increasing concentrations of EETEB (up to $1.5 \mathrm{mg} / \mathrm{ml}$ ) for $24 \mathrm{~h}$. Cells treated with (A) 0 (control group), (B) 0.75 , (C) 1.0 and (D) $1.5 \mathrm{mg} / \mathrm{ml}$ EETEB. Arrows indicate apoptotic phenomena in the mitochondria and karyotheca of the SGC-7901 cells. Scale bars, $5 \mu \mathrm{M}$. EETEB, ethanolic extract of Tulipa edulis Bak.

followed by FACS analysis. As indicated in Fig. 2A and B, following treatment with $0,0.75,1.0$ and $1.5 \mathrm{mg} / \mathrm{ml}$ EETEB, the percentage of cells undergoing early or late apoptosis was $8.90 \pm 0.81,14.31 \pm 1.13,18.28 \pm 2.32$ and $50.68 \pm 2.05 \%$, respectively. EETEB concentrations of 1.0 and $1.5 \mathrm{mg} / \mathrm{ml}$ resulted in a significant increase in apoptosis compared with 

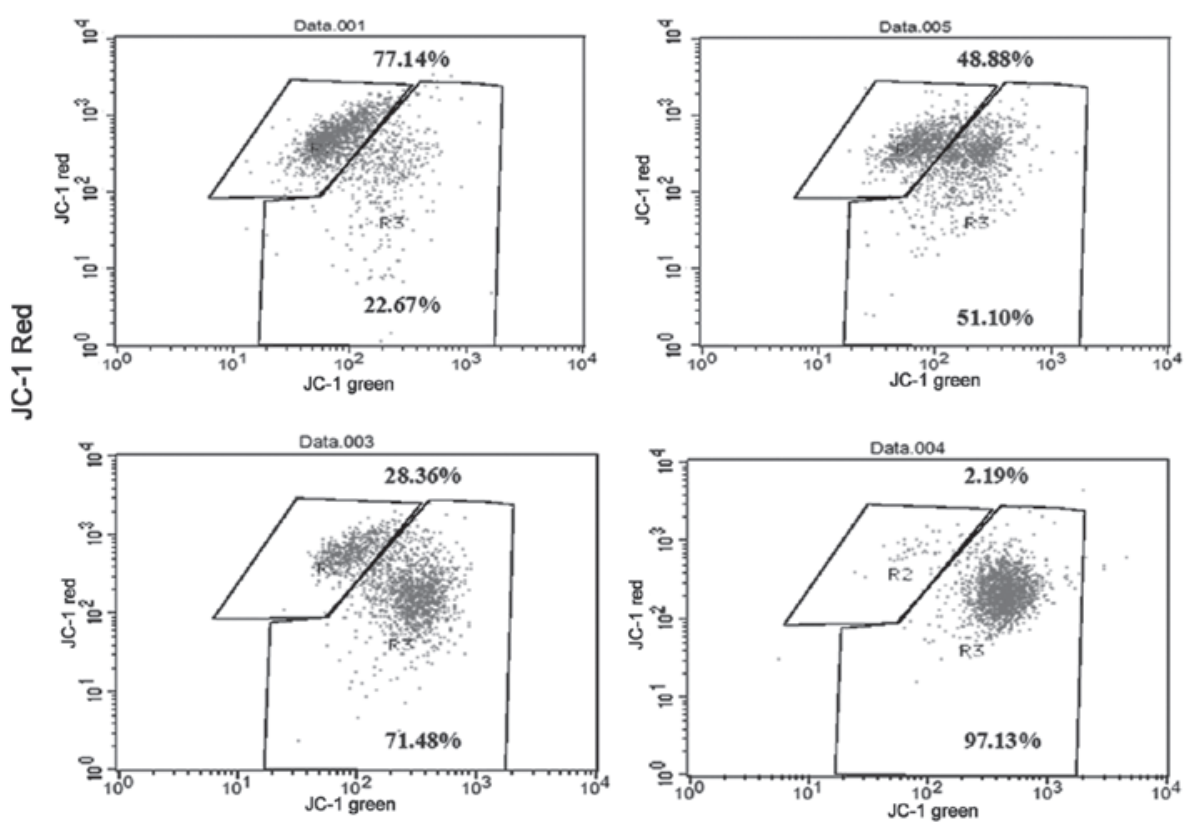

JC-1 Green

Figure 5. Effect of EETEB on the mitochondrial membrane potential in SGC-7901 gastric cancer cells. Cells were grown and treated with increasing concentrations of EETEB (up to $1.5 \mathrm{mg} / \mathrm{ml}$ ) for $24 \mathrm{~h}$. JC-1 fluorescent staining intensity was detected using fluorescence-activated cell sorting. EETEB, ethanolic extract of Tulipa edulis Bak.

the control group $(\mathrm{P}<0.05)$, indicating that EETEB promoted SGC-7901 cell apoptosis in a dose-dependent manner.

The promotion of cellular apoptosis by EETEB treatment was verified by examining nuclear morphological changes following staining of cell nuclei with the DNA-binding dye, DAPI. As indicated in Fig. 3, EETEB-treated cells (Fig. 3B-D) exhibited typical apoptotic morphological features, such as condensed chromatin and fragmented nuclei. By contrast, the untreated cell nuclei (Fig. 3A) exhibited homogenous and less intense staining.

The morphological effect of EETEB treatment on SGC-7901 cells was also evaluated using TEM. As demonstrated in Fig. 4A, untreated control cells did not display any morphological changes. However, EETEB treatment resulted in a decrease in the number of microvilli, shrinkage of the cytoplasmic organoid volume (as evidenced by the promotion of electron density), shrinkage of the nucleolus and margination of the heterochromatin (Fig. 4B-D).

EETEB induces the loss of mitochondrial membrane potential in $S G C-7901$ cells. Changes in the mitochondrial membrane potential were examined using FACS analysis with JC-1 staining. The membrane-permeable JC-1 dye exhibits potential-dependent accumulation in the mitochondria, indicated by a fluorescence emission shift from green (wavelength, $525 \mathrm{~nm}$ ) to red (wavelength, $\sim 590 \mathrm{~nm}$ ) (20). Therefore, a collapse in the mitochondrial membrane potential during apoptosis can be indicated by a decrease in the ratio of red/green fluorescence intensity. As demonstrated in Fig. 5, following treatment with 0, 0.75, 1.0 and $1.5 \mathrm{mg} / \mathrm{ml}$ EETEB, the JC-1 red/green fluorescence ratio in SGC-7901 cells was $22.67 \pm 0.56,51.10 \pm 1.25,71.48 \pm 1.18$ and $97.13 \pm 3.21 \%$, respectively. This indicated that EETEB treatment induced the loss of mitochondrial membrane potential in SGC-7901 cells in a dose-dependent manner.
A

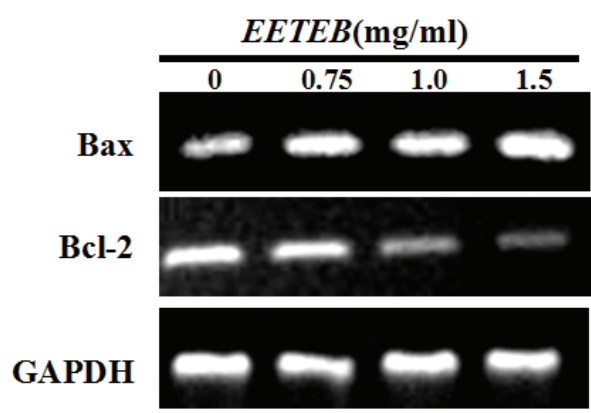

B

\section{$\operatorname{EETEB}(\mathrm{mg} / \mathrm{ml})$}

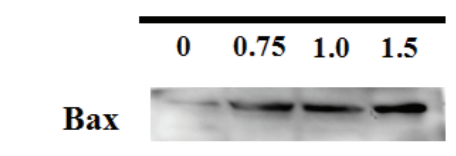

Bcl-2

$\beta$-actin

Figure 6. Effect of EETEB treatment on SGC-7901 cell apoptosis, based on the Bax and Bcl-2 expression levels. (A) Reverse transcription-polymerase chain reaction (RT-PCR) detection of Bax and Bcl-2 mRNA expression levels. The cells were grown and treated with increasing concentrations of EETEB (up to $1.5 \mathrm{mg} / \mathrm{ml}$ ) for $24 \mathrm{~h}$ prior to RT-PCR. GAPDH was used as the internal control. (B) Western blot analysis of $\mathrm{Bax}$ and $\mathrm{Bcl}-2$ protein expression levels. The cells were grown and treated with increasing concentrations of EETEB (up to $1.5 \mathrm{mg} / \mathrm{ml}$ ) for $24 \mathrm{~h}$ prior to western blotting. $\beta$-actin was used as the internal control. EETEB, ethanolic extract of Tulipa edulis Bak; Bcl-2, B-cell lymphoma-2; Bax, Bcl-2-associated X protein.

EETEB regulates the expression of Bcl-2 family members in SGC-7901 cells. The underlying mechanism mediating 
the pro-apoptotic activity of EETEB was investigated by performing RT-PCR to detect the mRNA expression levels and western blotting to determine the protein expression levels of Bcl-2 and Bax in SGC-7901 cells. As shown in Fig. 6, EETEB treatment markedly reduced the mRNA (Fig. 6A) and protein (Fig. 6B) expression levels of anti-apoptotic Bcl-2. By contrast, the expression of pro-apoptotic Bax appeared to be markedly increased following EETEB treatment, indicating that EETEB promoted SGC-7901 cell apoptosis by increasing the pro-apoptotic $\mathrm{Bax} / \mathrm{Bcl}-2$ ratio.

\section{Discussion}

An abnormal increase in cell proliferation or a reduction in cell apoptosis are two important characteristics of cancer cells (21). However, numerous currently used anticancer agents contain compounds that directly or indirectly damage healthy cells as well as cancer cells, limiting their long-term use and reducing their therapeutic efficacy $(22,23)$. These problems highlight the requirement for the development of novel therapeutic cancer agents. Traditional Chinese herbal medicine compounds, which exhibit relatively less side-effects, have been used in clinical settings to treat various types of disease, including GC. TEB has been used previously in numerous Traditional Chinese medicine herbal formulas for the treatment of cancer, thyreoitis and lymphadenitis without any toxic effects (24-27). Therefore, we hypothesized that TEB is not cytotoxic to healthy cells and thus healthy gastric cells were not used for comparison in the present study.

To the best of our knowledge, the present study is the first to report that EETEB appears to reduce viability and inhibit growth in human gastric carcinoma (SGC-7901) cells in a dose-dependent manner. Furthermore, the current study demonstrated that EETEB may induce SGC-7901 cell apoptosis. Thus far, the Bcl-2 family has been identified to mediate an apoptotic signaling pathway, the mitochondrial pathway (28). Bax and Bcl-2 are members of the Bcl-2 family of proteins regulates apoptosis (29). Bax is pro-apoptotic, and Bcl-2 is considered to be anti-apoptotic (30). Therefore, the expression of Bcl-2 or Bax may determine whether cancer cells progress towards apoptosis (9). In the present study, a marked change in the mRNA and protein expression patterns of Bcl-2 and Bax was observed following EETEB treatment. Furthermore, flow cytometry was performed, identifying that EETEB treatment caused a significant increase in cell apoptosis in a dose-dependent manner. Therefore, EETEB is hypothesized to result in cell apoptosis through a process that involves the opening of the mitochondrial permeability transition pore complex (31). In addition, the present study demonstrated that EETEB caused the loss of mitochondrial transmembrane potential, a factor that is considered to be a major determinant in cellular commitment to cellular apoptosis or death (32). Finally, TEM was used to observe the morphology of SGC-7901 cells treated with the EETEB. The results indicated that the number of cell microvilli and the cytoplasmic volume decreased, the electron density was promoted, the nucleolus decreased in size and the heterochromatin was marginated. Thus, the morphological changes detected in the SGC-7901 cells demonstrated apoptosis.
In conclusion, the present the results of the present study indicated that EETEB treatment may effectively kill the human GC cells, SGC-7901. Furthermore, the current data demonstrates, for the first time, that EETEB inhibits proliferation and induces apoptosis via the mitochondrial signaling pathway. However, it is important to note that the present study only examined the in vitro antitumor effects of EETEB. Therefore, the in vivo antitumor effects of EETEB, as well as potential molecular mechanisms, require further investigation.

\section{Acknowledgements}

The present study was supported by the Research Foundation of the Education Bureau of Fujian Province of China (grant no. JA11132).

\section{References}

1. Jemal A, Bray F, Center MM, Ferlay J, Ward E and Forman D: Global cancer statistics. CA Cancer J Clin 61: 69-90, 2011.

2. Sakuramoto S, Sasako M, Yamaguchi T, Kinoshita T, Fujii M, Nashimoto A, Furukawa H, Nakajima T, Ohashi Y, Imamura $\mathrm{H}$, et al; ACTS-GC Group: Adjuvant chemotherapy for gastric cancer with S-1, an oral fluoropyrimidine. N Engl J Med 357: 1810-1820, 2007.

3. Power DG, Kelsen DP and Shah MA: Advanced gastric cancer-slow but steady progress. Cancer Treat Rev 36: 384-392, 2010.

4. Park HR, Tomida A, Sato S, Tsukumo Y, Yun J, Yamori T, Hayakawa Y, Tsuruo T and Shin-ya K: Effect on tumor cells of blocking survival response to glucose deprivation. J Natl Cancer Inst 96: 1300-1310, 2004.

5. The State Pharmacopoeia Commission: Pharmacopoeia of People's Republic of China. Chin Med Sci Technol Press, Beijing, p31,2010.

6. Xia WB, Xue Z, Li S, Wang SJ, Yang YC, He DX, Ran GL, Kong LZ and Shi JG: Chemical constituents from tuber of Cremastra appendiculata. Zhongguo Zhong Yao Za Zhi 30: 1827-1830, 2005.

7. Feng D, Ma Y, Liu J, Xu L, Zhang Y, Qu J, Liu Y and Qu X: Cbl-b enhances sensitivity to 5-fluorouracil via GFR-and mitochondria-mediated pathways in gastric cancercells. Int J Mol Sci 14: 24399-24411, 2013.

8. Cory S, Huang DC and Adams JM: The Bcl-2 family: roles in cell survival and oncogenesis. Oncogene 22: 8590-8607, 2003.

9. Luo X, Budihardjo I, Zou H, Slaughter C and Wang X: Bid, a $\mathrm{Bcl}-2$ interacting protein, mediates cytochrome c release from mitochondria in response to activation of cell surface death receptors. Cell 94: 481-490, 1998.

10. Mathai JP, Germain M and Shore GC: BH3-only BIK regulates BAX,BAK-dependent release of $\mathrm{Ca}^{2+}$ from endoplasmic reticulum stores and mitochondrial apoptosis during stress-induced cell death. J Biol Chem 280: 23829-23836, 2005.

11. Martinou JC and Youle RJ: Mitochondria in apoptosis: Bcl-2 family members and mitochondrial dynamics. Dev Cell 21: 92-101, 2011.

12. Yuan J: Molecular control of life and death. Curr Opin Cell Biol 7: 211-214, 1995.

13. Saraste A and Pulkki K: Morphologic and biochemical hallmarks of apoptosis. Cardiovase Res 45: 528-537, 2000.

14. Boatright KM and Salvesen GS: Mechanisms of caspase activation. Curr Opin Cell Biol 15: 725-731, 2003.

15. Vaux DL and Korsmeyer SJ: Cell death in development. Cell 96: 245-254, 1999

16. Antonsson B, Montessuit S, Lauper S, Eskes R and Martinou JC: Bax oligomerization is required for channel-forming activity in liposomes and to trigger cytochrome $\mathrm{C}$ release from mitochondria. Biochem J 345: 271-278, 2000.

17. O'Neill J, Manion M, Schwartz P and Hockenbery DM: Promises and challenges of targeting Bcl-2 anti-apoptotic proteins for cancer therapy. Biochim Biophys Acta 1705: 43-51, 2004.

18. Orrenius S: Mitochondrial regulation of apoptotic cell death. Toxicol Lett 149: 19-23, 2004. 
19. Lin R, Li Z, Zeng J, Lin J and Peng J: Effect of Pseudobulbus Cremastrae seu Pleiones (EEPCP) on human gastric carcinoma SGC-7901 cells. Fujian Zhong Yi Yao Da Xue Xue Bao 22: 22-24, 2012 (In Chinese).

20. Yokosuka T, Goto H, Fujii H, et al: Flow cytometric chemosensitivity assay using $\mathrm{JC} 1$, a sensor of mitochondrial transmembrane potential, in acute leukemia. Cancer Chemother Pharmacol 72: 1335-1342, 2013.

21. Adams JM and Cory S: The Bcl-2 apoptotic switch in cancer development and therapy. Oncogene 26: 1324-1337, 2007.

22. Boos G and Stopper H: Genotoxicity of several clinically used topoisomerase II inhibitors. Toxicol Lett 116: 7-16, 2000.

23. Gordaliza M: Natural products as leads to anticancer drugs. Clin Transl Oncol 9: 767-776, 2007

24. Chen LW, Lin J, Chen W and Zhang W: Effect of Chinese herbal medicine on patients with primary hepatic carcinoma in III stage during perioperational period: a report of 42 cases. Zhongguo Zhong Xi Yi Jie He Za Zhi 25: 832-834, 2005 (In Chinese).

25. Chen L, Zheng C and Du J: Study on antitumor mechanism of Qingre Xiaozheng drink by molecular docking method. Clin Pharmacol Ther (Chin) 12: 324-328, 2007.

26. Cao Z, Lin W, Huang Z, Chen X, Zhao J, Zheng L, Ye H, Liu Z, Liao L and Du J: Ethyl acetate extraction from a Chinese herbal formula, Jiedu Xiaozheng Yin, inhibits the proliferation of hepatocellular carcinoma cells via induction of G0/G1 phase arrest in vivo and in vitro. Int J Oncol 42: 202-210, 2013.
27. Cao Z, Lin W, Huang Z, Chen X, Zhao J, Zheng L, Ye H, Liu Z, Liao L and Du J: Jiedu Xiaozheng Yin, a Chinese herbal formula, inhibits tumor angiogenesis via downregulation of VEGF-A and VEGFR-2 expression in vivo and in vitro. Oncol Rep 29: 1080-1086, 2013.

28. Hossini AM and Eberle J: Apoptosis induction by Bcl-2 proteins independent of the $\mathrm{BH} 3$ domain. Biochem Pharmacol 76: 1612-1619, 2008.

29. Gabriel B, Sureau F, Casselyn M, Teissié J and Petit PX: Retroactive pathway involving mitochondria in electroloaded cytochrome c-induced apoptosis. Protective properties of Bcl-2 and Bcl-XL. Exp Cell Res 289: 195-210, 2003.

30. Lang-Rollin I, Maniati M, Jabado O, Vekrellis K, Papantonis S, Rideout HJ and Stefanis L: Apoptosis and the conformational change of Bax induced by proteasomal inhibition of PC12 cells are inhibited by Bcl-xL and Bcl-2. Apoptosis 10: 809-820, 2005.

31. Bouaziz C, Martel C, Sharaf el dein O, Abid-Essefi S, Brenner C, Lemaire C and Bacha H: Fusarial toxin-induced toxicity in cultured cells and in isolated mitochondria involves PTPC-dependent activation of the mitochondrial pathway of apoptosis. Toxicol Sci 110: 363-375, 2009.

32. Bras M, Queenan B and Susin SA: Programmed cell death via mitochondria: Different modes of dying. Biochemistry (Mosc) 70: 231-239, 2005. 